\title{
Xanthan Gum by Xanthomonas Campestris as Printing Thickener on Cotton Fabrics with Reactive Dyes
}

\author{
Srie Gustiani ${ }^{1}$, Cica Kasipah ${ }^{2}$, Qomarudin Helmy ${ }^{3}$ \\ \{srigustiani@gmail.com¹, chichakays@gmail.com², helmy@tl.itb.ac.id ${ }^{3}$ \}
}

Center for Textile, Indonesian Ministry of Industry, 390 Jenderal Ahmad Yani, Bandung, Indonesia ${ }^{1}$, Water and Wastewater Research Group, Institut Teknologi Bandung, 10 Ganesa, Bandung, Indonesia ${ }^{2}$

\begin{abstract}
Xanthan gum is one of the natural extracellular polysaccharide, which is produced by the bacterium Xanthomonas campestris and by other species of Xanthomonas, with good rheological characteristics, is used as thickener for textile printing process. In this study, xanthan gum (produce by X. campestris using tofu dregs as its carbon source) was used as a printing thickener on cotton fabrics and its performance comparation with commercial xanthan gum and sodium alginate was presented. Printing characteristics were evaluated by measuring K/S value, the stiffness of fabrics and color fastness properties to rubbing, washing, sweat, and sunlight according to SNI ISO 105-C06-2010. The results showed that xanthan gum produced from tofu dregs bio-conversion has a good performance to overall color fastness properties when used as a thickener on cotton fabrics with reactive dyes. Color fastness to dry give a value of 4-5 and wet rubbing of 3-4, higher than commercial xanthan gum and alginate that give value of 3 and 3-4. Color fastness to washing (value of color stains) gives a value of 4-5, higher than the commercial xanthan gum that give a value of 4 and similar with sodium alginate. A similar result was found that xanthan gum from tofu dregs has a higher performance of $\mathrm{K} / \mathrm{S}$ with a value of 11.949 compared to its commercial counterpart that gives a value of 4.476 . The stiffness of cotton fabrics using xanthan gum produced from tofu dregs was higher than commercial xanthan gum in the textile printing process with reactive dyes. Xanthan gum from tofu dregs has good performance for application in the textile printing process with reactive dyes.
\end{abstract}

Keywords: Color Fastness, Stiffness, K/S, Cotton, Printing, Reactive Dyes.

\section{Introduction}

Textile fabric printing is the process of applying colors to a textile fabric in the intended design and pattern. A thick paste of dye is used in printing to prevent the color from spreading to undesired area by capillary effect; therefore the role of a thickener is important to this process. Textile printing pastes are usually used to transfer dyes or pigments onto a textile material in a controlled way [1]. Printing pastes are usually prepared by solubilizing thickening agents in water with good screen-ability and a uniform penetrability into the fabrics [2]. Thickening agents are very important in the formulation of printing pastes, and must be compatible with other additives[3].

In the textile industries, the majority of printed materials is cotton fabrics and is generally colored with reactive dyes. A successful print depend on the type of thickener used, ensured through the modulation sharpness of mark, good hand, clean drawing pattern, rheological 
properties, preventing dye migration, also a homogenous distribution of the printing paste on the screen and its uniform flow through the screen openings [3][4]. Sodium alginate and guar gum are commonly used as thickener for cotton printing [4][5]. Polysaccharides and its derivatives with high molecular weight are widely used in textile applications for sizing, textile coating and finishing agents, also in textile printing as a thickener. Selection of thickener determined by the type of fabric to be printed, the printing conditions, the type of dye used. Depending on the chemical structure, dyes may interact with thickening agents. Alginates and xanthan gum are excellent thickeners for printing application, because they are non-reactive with hydrodynamic thickener and can impart high viscosities at low concentration. Xanthan gum is one of the natural extracellular polysaccharide, which is produced by the bacterium Xanthomonas campestris and by other species of Xanthomonas, with good rheological characteristics such as a high degree of pseudoplasticity, a high viscosity even at low concentration, stability and compatibility with most metallic salts, excellent solubility and stability in acidic and alkaline solutions, can be substituting sodium alginate [6]. Color fastness to wash, color fastness to rubbing, color fastness to sweat, color fastness to sunlight, sharpness, handling, are importance properties for printing.

The important materials for the formulation of printing paste are the colorant and the thickener system. Different fibers have an affinity to different dyes e.g. reactive dyes are usually used for printing on cellulosic fabrics, while disperse dyes are commonly used to color synthetic fibers such as polyester. In the printing textile process, natural thickeners such as sodium alginate (SA) are commonly used and excellent for printing application. SA has good properties, high viscosities at low concentrations and good rheology.

The purpose of this work was to study the use of xanthan gum produced by Xanthomonas campestris using tofu dregs as its carbon source and used as a printing thickener on cotton fabrics.

\section{Experimental}

\subsection{Chemicals}

Chemicals used in this work are both AR (analytical reagent) and LR (laboratory reagent) grade purchased from Merck, Sigma-Aldrich, and Brataco Chemica. Xanthomonas campestris was obtained from environmental laboratory culture collection of biotechnology and bioscience research center, Institut Teknologi Bandung.

\subsection{Preparation of the printing paste and printing process}

Thickening agent preparation: Thickening agent was prepared by using xanthan gum tofu dregs, xanthan gum commercial and sodium alginate $5 \% \mathrm{w} / \mathrm{v}$ respectively. The dispersion mixture was stirred following by adding the water until a thick emulsion was formed.

Printing paste preparation: The printing paste for reactive dyes printing on cotton fabrics was prepared using the following composition (Table 1). All ingredients are thoroughly mixed 
using an electric stirrer until they become a paste. Add enough deionized water to form a paste weighing $1 \mathrm{~kg}$.

Printing procedure: Cotton was printed using the flat hand screen technique. The print paste was spread across the screen and squeezed by a squeegee for passing the paste through the screen. Printed samples were dried at $100{ }^{\circ} \mathrm{C}$ for $2 \mathrm{~min}$ and fixed by superheated steam at 180 ${ }^{\circ} \mathrm{C}$ for $1 \mathrm{~min}$. Printing samples were rinsed with cold water for $15 \mathrm{~min}$ and then hot water for $15 \mathrm{~min}$ at $80{ }^{\circ} \mathrm{C}$, followed by soaping agent $2 \mathrm{ml} / \mathrm{l}$, then rinsed well and air dried at room temperature [7].

Table 1. Composition of the printing paste in $1 \mathrm{~kg}$

\begin{tabular}{lcc}
\hline Material & Unit & Value \\
\hline Thickening agent & $\mathrm{g}$ & 700 \\
Urea & $\mathrm{g}$ & 20 \\
Resist salt & $\mathrm{g}$ & 1 \\
Reactive dyes & $\mathrm{g}$ & 30 \\
Sodium carbonate & $\mathrm{g}$ & 2 \\
Deionized water & $\mathrm{g}$ & 247 \\
\hline
\end{tabular}

Color value: The printed samples were assessed for the depth of color strength and Fastness properties. The color strength $(\mathrm{K} / \mathrm{S})$ value was evaluated using a spectrophotometer. The K/S is a function of color depth and calculated by the Kubelka-Munk equation [8][9]:

$$
\frac{K}{S}=\frac{(1-R)^{2}}{2 R}
$$

Where $\mathrm{R}$ is the reflectance at complete opacity, $\mathrm{K}$ is the absorption coefficient, and $\mathrm{S}$ is the scarttering coefficient.

Fastness testing: Color fastness properties for rubbing fastness, washing fastness, sweat fastness, and sunlight fastness of the dyed samples were evaluated according to SNI ISO 105X12:2012, SNI ISO 105-C06:2010, SNI ISO 105-E04:2010, SNI ISO 105-B01:2010, respectively [[10],[11],[12],[13]].

\section{Result and discussion}

Color Value: A study on reactive printing with three different of thickening agent (xanthan gum tofu dregs, commercial xanthan gum, sodium alginate) was carried out. The effect of different thickeners on color value has been shown in Table 2. K/S value of samples printed with xanthan gum (tofu dregs), commercial xanthan gum and sodium alginate are 11.946; 3.894; and 5.844, respectively. Xanthan gum (tofu dregs) was the best printed result, and the next good results were observed for sodium alginate and commercial xanthan gum, respectively. The higher the K/S value are the better, that mean the depth of color of the printed sample (Fig. 1). 
Table 2. Color value of printed cotton fabric using different of thickening agent

\begin{tabular}{|c|c|c|c|c|c|c|c|c|}
\hline $\begin{array}{l}\text { Thickening } \\
\text { Agent }\end{array}$ & Area & $\mathrm{K} / \mathrm{S}$ & $\mathrm{L}^{*}$ & $a^{*}$ & $b^{*}$ & $\Delta \mathrm{E}$ & Handling & $\begin{array}{c}\text { Sharpness } \\
\text { level }\end{array}$ \\
\hline $\begin{array}{l}\text { Xanthan gum } \\
\text { (tofu dregs) }\end{array}$ & Up & 11.946 & 37.73 & 6.47 & -40.39 & & $\begin{array}{l}\text { Very } \\
\text { Good }\end{array}$ & $\begin{array}{l}\text { Very } \\
\text { Good }\end{array}$ \\
\hline $\begin{array}{l}\text { Commercial } \\
\text { xanthan gum }\end{array}$ & Up & 3.894 & 47.42 & 6.15 & -35.85 & $\begin{array}{l}6.36 \\
\text { (high) }\end{array}$ & Good & Good \\
\hline $\begin{array}{l}\text { Sodium } \\
\text { alginate }\end{array}$ & Up & 5.844 & 36.60 & 6.59 & -23.83 & $\begin{array}{c}7.72 \\
\text { (high) }\end{array}$ & Good & Good \\
\hline
\end{tabular}

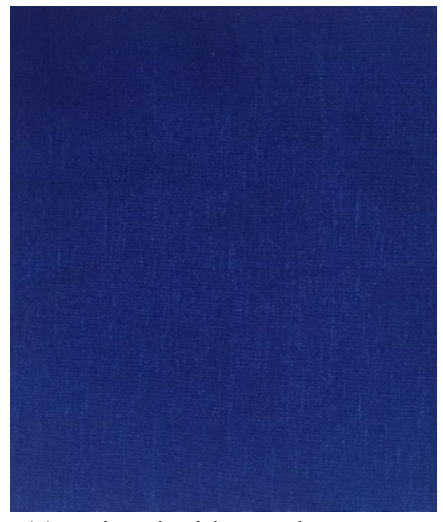

(a). Printed with Xanthan gum tofu dregs

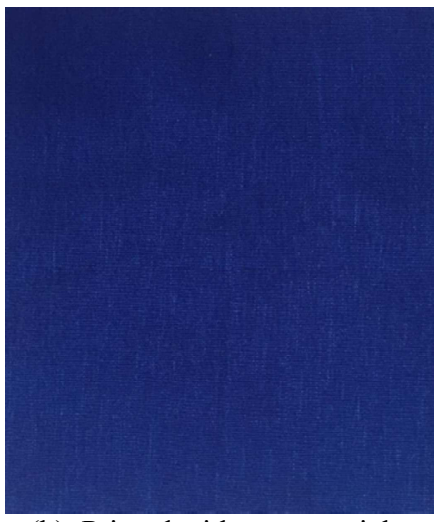

(b). Printed with commercial Xanthan gum

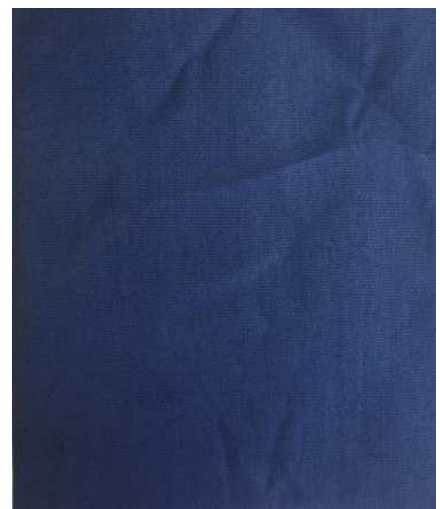

(c) Printed with Alginate

Fig.1. Cotton fabrics printed by thickeners

Table 3. Color fastness of printed cotton fabric using different of thickening agent

\begin{tabular}{|c|c|c|c|c|}
\hline \multirow{2}{*}{\multicolumn{2}{|c|}{ Color Fastness }} & \multicolumn{3}{|c|}{$\begin{array}{r}\text { Thickening Agent } \\
\end{array}$} \\
\hline & & \multirow{2}{*}{$\begin{array}{c}\begin{array}{c}\text { Xanthan gum } \\
\text { (tofu dregs) }\end{array} \\
3-4\end{array}$} & \multirow{2}{*}{$\begin{array}{l}\begin{array}{r}\text { Commercial } \\
\text { xanthan gum }\end{array} \\
3\end{array}$} & \multirow{2}{*}{$\begin{array}{c}\begin{array}{c}\text { Sodium } \\
\text { alginate }\end{array} \\
3-4\end{array}$} \\
\hline Rubbing (SNI ISO & Wet & & & \\
\hline 105-X12: 2012) & Dry & $4-5$ & $4-5$ & 4-5 \\
\hline Washing (SNI ISO & Change of color & $4-5$ & 4 & $4-5$ \\
\hline \multirow[t]{2}{*}{ 105-C06: 2010) } & Stain of color & $4-5$ & 3 & $4-5$ \\
\hline & Change Acid & $4-5$ & 4 & $4-5$ \\
\hline Sweat (SNI ISO & of color & $4-5$ & 4 & $4-5$ \\
\hline \multirow[t]{2}{*}{ 105-E04 : 2010) } & Stain of & $3-4$ & $4-5$ & $4-5$ \\
\hline & color Base & 4 & $4-5$ & $4-5$ \\
\hline \multicolumn{2}{|c|}{ Sunlight (SNI ISO 105-B01: 2010) } & $4-5$ & $3-4$ & 4 \\
\hline
\end{tabular}

Where, $1=$ very poor; $2=$ poor; $3=$ Good; $4=$ very good; and $5=$ excellent

Printed results using xanthan gum (tofu dregs) also shows a good handling properties and sharpness level, as shown in Table 2 and Figure 1. The study results, showed that the depth of the color (K/S value), xanthan gum tofu dregs was the 11.946; 5.844; and 3.894, respectively. The handling properties and sharpness level of xanthan gum (tofu dregs) give the best printed result compared with sodium alginate and its commercial counterpart. Fastness properties analysis of washing, rubbing, sweat and sunlight fastness of printed cotton fabrics using 
thickeners from xanthan gum (tofu dregs), sodium alginate and xanthan gum commercial as thickening agents are presented in Table 3. The washing fastness rating of printed cotton fabrics with xanthan gum (tofu dregs) is very good, similar result to sodium alginate thickener (4-5).

The shift to an era of more environmentally friendly products has encouraged the industry to create eco-green products with low environmental impact. The use of natural and/or biobased material such as fibres (coffee ground, banana, hemp, lotus, pineapple, etc); biosurfactant; bio-detergent; oleochemicals; natural dyes; and other bio-based materials draws much attention worldwide to date [[14],[15],[16]].

\section{References}

[1] Dario, C., Marco, Z., Stefania, V., Maurizio, G. and Michele, M.: Thickening Compositions for Textile Printing Paste. International Application No. PCT/EP2016/081049, Patent Cooperation Treaty (2017).

[2] Wang, L., Zhu, F. and Lu, D.: Rheological properties of sodium alginate and xanthan pastes on cotton with reactive dye in screen printing. Textile Research Journal, 83 (17): 1873-1884 (2013)

[3] Madhu, C. R. and Patel, M. C.: Reactive Dye Printing on Cotton with Natural and Synthetic Thickeners, International Research Journal of Engineering and Technology, Vol 03 (2016)"

[4] Akbarzadeh, A., Kermani, B., Nasrabadi, M. A. and Najafi, H.: Application of new reactive and disperse dye on textile dyeing, printing with acrylate Eco friendly copolymers. International Journal of the Physical Sciences, Vol 6(21): 4903-4909 (2011)

[5] Kesarwani, P.: Cotton fabric printing with reactive dye using guar gum, The Indian Textile Journal (2009).

[6] Gustiani, S., Helmy, Q., Kasipah, C. and Novarini, E.: Produksi dan karakterisasi gum xanthan dari ampas tahu sebagai pengental pada proses tekstil. Arena Tekstil. 32(2): 51-58 (2017).

[7] Ahmad, B., Bhatti, I. A., Bhatti, H. N. and Abbas, M.: A Study of Physico-Chemical Properties, Exhaust Dyeing of Cotton with Synthesized azo-reactive Dyes and Their Printing Applications. International Journal of Basic \& Applied Sciences IJBAS-IJENS, 12 (6): 137142 (2012).

[8] Kubelka, P. and Munk, F.: Ein Beitrag Zur Optik Der Farbanstriche. Z. Techn. Phys., 12, 593601 (1931).

[9] Hossain, Md. F., Asaduzzaman, Md., Kamruzzaman, Md., Talukder, Md.E., Miah, M.R. and Quan, H: Application of New Synthetic Fifth Generation Thickeners for Printing Cotton Fabric with Reactive Dyes. American Journal of Polymer Science \& Engineering, 4:123-

[10] SNI ISO 105-X12: Test for colour fastness-part X12: colour fastness to rubbing (2012). .

[11] SNI ISO 105-C06: Test for colour fastness-part C06: colour fastness to domestic and commercial laundering (2010). .

[12] SNI ISO 105-E04: Test for colour fastness-part E04: colour fastness to perspiration (2010). .

[13] SNI ISO 105-B01: Test for colour fastness-part B01: colour fastness to light (2010).

[14] Eryuruk, S.H.: Greening of the Textile and Clothing Industry. Fibres \& Textiles in Eastern Europe, 20(95): 22-27 (2012).

[15] Helmy, Q., Kardena, E., Funamizu, N and Wisjnuprapto: Strategies toward commercial scale of biosurfactant production as potential substitute for it's chemically counterparts, International Journal of Biotechnology 12 (1-2): 66-86 (2011).

[16] Aktar, Mst.A.: Green Insights of Textile Industry in Bangladesh: A Case Study on Mozart Knitting Ltd., Global Disclosure of Economics and Business, 3(2):45-60 (2014). 